\title{
SYSTEMATIC REVIEW: A LITERATURE REVIEW ON SYSTEMATIC INTEGRATIVE INTERVENTION MODEL FOR KLITIH ISSUE IN YOGYAKARTA
}

\section{Dody Hartanto*, Mufied Fauziah, Ewang Sewoko, Karsih *Correspondent Author}

\author{
Dody Hartanto \\ Universitas Ahmad Dahlan \\ Jalan Ring Road Selatan Yogyakarta, \\ Indonesia \\ Email: dody.hartanto@bk.uad.ac.id \\ Mufied Fauziah \\ Universitas Ahmad Dahlan \\ Jalan Ring Road Selatan Yogyakarta, \\ Indonesia \\ Email: mufied.fauziah@bk.uad.ac.id \\ Ewang Sewoko \\ BKKBN DIY \\ Jalan Kenari Nomor 58, Muja Muju, \\ Umbulharjo, Yogyakarta \\ Indonesia \\ Email: ewang_sewoko@yahoo.com \\ Karsih \\ Universitas Negeri Jakarta \\ Jalan Rawamangun Muka, Jakarta Timur \\ Indonesia \\ Email:karsih@unj.ac.id
}

Page

94-99

\begin{abstract}
Klitih constitutes a juvenile delinquency that has reached an alarming level as the case keep occurs every year. This study aims to design the intervention model for handling (preventive-solution) klitih problem in the Special Region of Yogyakarta, Indonesia. This systematic review summarized results of primary study to provide more comprehensive, balanced fact. Data were obtained from articles in research journals about klitih. 297 Articles on klitih published between 2017-2020 were found. Of these articles, eleven articles were selected based on their relevance to the research question of this study. The data were contentanalyzed, resulting in three important categories: family, school, and community. The family plays an important role in satisfying basic adolescents needs and internalizing positive values. Meanwhile, the school functions to identify students prone to juvenile delinquency and perform preventive, curative, and preservative plans for these students. Lastly, the community's role is to provide a positive learning environment for students and sufficient activity to provide adolescents with various opportunities. The results of the study can be used as a reference for school counselors when handling klitih problem.
\end{abstract}

Keywords: strategic solution, intervention model, klitih

\section{INTRODUCTION}

Adolescents can be easily influenced as they are still in the effort of finding their selfidentity and are excessively sensitive, which tends to lead to narcissistic behavior. Adolescents often face various problems. Some of them, in Indonesia, even face legal issues. Census conducted by Statistics Indonesia shows that the Indonesian population in 2020 was 270.203 .917 people. From that number, 23.749.949 were adolescents between 10-14 years of age $(12,248,242$ boys and 11,501,707 girls). Meanwhile, 23,122,993 of them were 


\title{
95 | PSIKOPEDAGOGIA
}

\author{
JURNAL BIMBINGAN DAN KONSELING
}

Vol.10, No.2, December 2021

adolescents aged 15-19 years old (11,890,104 boys and 11,232,889 girls).

The specialty of the Special Region of Yogyakarta (DIY) lies in its human resources. Human resources have become the key determining the future of DIY, particularly its young generation Citizen in Yogyakarta in the 80 s-90s used to hang out late at night, look for dinner, or just to catch some fresh air. Local people often referred to these activities to the term "klitih." Over time, the meaning of the word "klitih" shifts as some groups of youth commit negative actions to look for identity (Hidayat, 2018).

The term klitih recently refers to a type of juvenile delinquencies that occurs in Yogyakarta. In klitih, perpetrators mainly aim to harm or even murder the victim using sharp objects like knives or even katana. Perpetrators usually choose their victims randomly, women, men, or even elders. This phenomenon damages Yogyakarta's reputation as the city of education (Atum, 2019).

Some klitih victims even as they are assaulted by rocks or sharp objects. Provincial Police Department of DIY reports a different number of klitih cases every year. In 2017, there were 51 violence cases of youth violence. Meanwhile, in 2018, 45 cases were reported. Then in 2019, 35 cases were reported in 5 cases were reported in January 2020. From the last forty cases reported in 2019 and 2020, a total of 81 perpetrators were arrested, and 57 (approximately 70\%) of them were students.

Various efforts have been made to solve this klitih problem. The most often approach is made by involving the school and the police. The police institution has also made various efforts to handle klitih, one of which is done by applying criminal profiling. Another attempt is made through a positive school climate approach. Teachers play pivotal roles in mapping this problem as it is assumed that this misbehavior involves students from the same school, resulting from a negative peer environment. The existing approaches to this problem still fail to solve the issue comprehensively.
Responding to this concerning issue, this study attempts to describe the intervention models in handling juvenile delinquency (preventive-solution), particularly klitih, in Yogyakarta. The result of this study can serve as the basis to determine the appropriate guidance and counseling for adolescents suspected to commit klitih.

\section{RESEARCH METHOD}

This qualitative systematic review summed up primary studies to present existing facts in a comprehensive and fair manner. 297 Articles were found in Google Scholar using the keyword "Klitih" in the last five years (2017-2021). These articles were filtered out in order to obtain the most relevant articles to answer the research question, "What is the intervention model of juvenile delinquency (preventive-solution) "klitih" in Special Region of Yogyakarta?" Eventually, eleven relevant articles were selected to answer the research question. The data were processed and classified into several categories using content analysis.

\section{RESULT AND DISCUSSION}

The data processed in this study were obtained from eleven articles displayed in table 1.

Table 1

Articles Study

\begin{tabular}{|c|c|}
\hline \multicolumn{2}{|r|}{ Articles Study } \\
\hline Author(s) & $\begin{array}{l}\text { Finding } \\
\end{array}$ \\
\hline $\begin{array}{l}\text { Moranita \& } \\
\text { Huda (2019) }\end{array}$ & $\begin{array}{l}\text { Family serves as the most dominant } \\
\text { factor in developing adolescents' }\end{array}$ \\
\hline & $\begin{array}{l}\text { self-concept, in addition to } \\
\text { community, peer, and learning } \\
\text { outcomes. }\end{array}$ \\
\hline $\begin{array}{l}\text { Sarwono } \\
(2017)\end{array}$ & $\begin{array}{l}\text { Family is deemed as a significant } \\
\text { agent in minimize } \\
\text { juvenile } \\
\text { delinquency } \\
\text { adolescents' by }\end{array}$ \\
\hline $\begin{array}{l}\text { Hastasari, } \\
\text { Suranto \& }\end{array}$ & $\begin{array}{l}\text { psychological, and social needs. } \\
\text { Authors assert the importance of } \\
\text { multidirectional communication to }\end{array}$ \\
\hline Hajaror (2018) & provide adolescents with \\
\hline & $\begin{array}{l}\text { opportunities to express themselves } \\
\text { and make a positive decision for } \\
\text { their life. }\end{array}$ \\
\hline Leonardus \& & Appropriate communication allows \\
\hline Nugroho (2017) & $\begin{array}{l}\text { internalization of life values such as } \\
\text { trust, freedom, compassion, } \\
\text { fairness, peace, and respect }\end{array}$ \\
\hline $\begin{array}{l}\text { Wiryawan \& } \\
\text { Yeremias } \\
(2021)\end{array}$ & $\begin{array}{l}\text { School plays active roles in } \\
\text { identifying schools affiliated with } \\
\text { school gangs. Providing students } \\
\text { with positive activities to spend their } \\
\text { spare time can be a strategic in } \\
\text { reducing juvenile delinquency. }\end{array}$ \\
\hline
\end{tabular}




\begin{tabular}{ll}
\hline Sukirno, S. & $\begin{array}{l}\text { Another alternative to spend } \\
\text { (2018) }\end{array}$ \\
students' spare time is by \\
developing reading habit to develop \\
students' character.
\end{tabular}

Efforts to minimize klitih in Yogyakarta require support from all community layers to create a healthy learning environment for adolescents. Ki Hajar Dewantara proposes a concept of education tri center, in which family, school, and community environment serve as the main actor in determining a student's educational success. The concept of education tri center proposed by Ki Hajar Dewantara is consistent with the discussion in this study, in which family, school, and community play pivotal roles in reducing adolescents' aggressiveness.

Fuadi, A., Muti'ah, T., Hartosujono (2019) defines klitih as the misbehavior of harming others people at night, either accidentally or on purpose. It denotes one type of aggressive behavior. According to Atkinson \& Hilgard, aggressiveness refers to a behavior aiming to harm others physically or verbally or damaging other people's property (Saputra et al., 2017).

It constitutes one of juvenile delinquency, i.e., sociopathological symptoms among adolescents due to social ignorance, which causes them to exhibit deviant behaviors (Kartono, as cited in Maulana 2019).

There are several complex risk factors contributing to juvenile delinquency, including family, financial problems, education, peers, etc. (Peiying: 2011). Family serves as the foundation of a community that functions to develop a social strength of an individual. It serves as the center of children's development from which they learn positive and negative behaviors. Every child faces a risk of juvenile delinquency, whether those abandoned by their parents, living with a single parent, complete parents, or guardian.

The result of the literature review presented in table 1 shows that the family and school play an important role in developing individuals' self-concept and emotion regulation skills to minimize juvenile delinquency. Muawanah et al. (2012) state that the proportion of juvenile delinquency can be accounted for

by emotional maturity and self-concept. Emotional maturity and self-concept are found to simultaneously predict juvenile delinquency.

The family also plays an important role in fulfilling basic human needs. Juvenile delinquency is one of the forms of misbehaviors requiring special attention and proper understanding. Appropriate handling of this issue can significantly affect adolescents' success in their next life phase, considering that adolescence is the most decisive transitional phase. Parents possess several alternatives in handling juvenile adolescents, including family guidance. Creating a harmonious, communicative, and comfortable family environment can help adolescents' personal and social adjustment processes (Andriyani: 2020). By providing such a family environment, adolescents can develop optimal religious and prosocial character behavior.

Bandura's social learning theory suggests that humans, including children, learn by imitating what they see in their surroundings (Heves, 2017). In this case, children possibly imitate misbehaviors they witness, such as drug abuse and violence, without realizing that such behaviors are inappropriate. This 


\section{7| PSIKOPEDAGOGIA}

JURNAL BIMBINGAN DAN KONSELING

Vol.10, No.2, December 2021

problem is worsened due to weak family structure, creating an uncomfortable family atmosphere for children during their childhood, which is associated with criminal behaviors when they grow. Children raised by a single parent exhibit a higher tendency to commit crimes as they lack parents' attention, affection, and guidance. This condition can occur because a single parent has to work to provide for his/her children. In other words, it can be assumed that a weak family structure can significantly contribute to the alarming increase in juvenile delinquency reported in the last few years.

In addition to the family, the school also plays a pivotal role in overcoming issues on klitih. School becomes one of the agents responsible for identifying any school gang and conducting preventive measures to prevent its students' aggressive behavior. School can be a conducive space to provide students with positive-productive activities. It is necessary to design interesting activities that suit students' hobbies to distribute students' excess energy to positive behaviors. School also needs to develop a peaceful climate and facilitate students to be more aware of their surroundings, especially regarding any form of violence. By involving all school members' role in creating a peaceful environment, juvenile delinquency rate, especially klitih, can be minimized.

Klitih becomes a public concern that requires attention and solution from the community itself by creating a supportive and positive culture that facilitates adolescents' development. Karlina (2020) suggests that the community plays a pivotal role in preventing juvenile delinquency by (1) speaking to adolescents who violate the norms, (2) becoming a good model for them, and (3) conducting activities that involve adolescents' roles.

The community also needs to optimize social networks to prevent misbehaviors (Hawkins and Weis, 2017). When group member is included in a social network, they are likely to feel empowered by the community. As a result, the community can establish a set of rules that can be implemented by the young generation. Thus, they may see a crime as risky and unacceptable behavior.

Three models are proposed to bridge various causes of juvenile delinquency currently faced by the community. First, parenting training, a program designed to improve parents' responsibility and behavior when caring for their children. Second, a family counseling, this program involves a combination of counseling skills and a trained resource. The counseling program can be divided into two categories: (1) the counseling for families showing emotional and behavioral problems and (2) families identified as having children committing klitih. Third, familycommunity integration, this program can be in the form of economic empowerment, education, and health program (integrated approach programs).

These three intervention models are designed by considering the effectiveness of the implementation, its positive impacts and replicability and adhering to the predetermined evaluation principle. The preventive-solution intervention model is a model attempting to mitigate the root cause of a problem. This proposed model also attempts to see the real-life condition encountered by adolescents within their family and environment when making a decision regarding the intervention. It possibly applies a single intervention or a combination of several interventions.

A strategic plan including preventive, curative, and preservative measure needs to be thoroughly designed to solve klitih problems. The strategic plan proposed in this study include:

1. The development of an accompaniment program for families facing difficulty in guiding their adolescents, especially in developing a communication pattern, identifying adolescents' needs, and developing a positive self-concept.

2. It is important to involve the family in monitoring and controlling adolescents' activity during their spare time.

3. School can be empowered to identify any school gang and monitor and guide adolescents affiliated with school gang. 
4. School needs to accurately identify students' character and provide them with suitable activities to fill their spare time.

5. Community needs to involve adolescents in various events to make them more productive.

6. It is also urgent to provide a village with a counselor to focus on preventing and handling adolescents' issue.

\section{CONCLUSION}

Collaborative efforts among different elements, i.e., family, school, and community, are required to solve klitih issues in Yogyakarta. Family plays a pivotal role in fulfilling adolescents' basic needs and internalizing positive social values they should possess. Meanwhile, school functions to identify students prone to juvenile delinquency and conduct preventive, curative, and preservative plans for such students. The community is also responsible for creating a positive learning environment and providing them with adequate activities. This study can be used as the basis to determine appropriate guidance and counseling services to prevent and eradicate klitih at school.

\section{REFERENCES}

Agnew, R. (2019). The Rise Of Social Control Theory, Fall Of Classic Strain Theory, And Reconciliation Between Social Control And General Strain Theories. In Book: Fifty Years Of Causes Of Delinquency, The Criminology Of Travis Hirschi, 25, 29- 44)

Alhadi, Said Dkk (2019) Self-Regulation Of Emotion In Students In Yogyakarta Indonesia: Gender Differences. Jurnal Kajian Bimbingan Dan Konseling. 4 (3), 82-87.

Andriyani, Juli (2020). Peran Lingkungan Keluarga Dalam Mengatasi Kenakalan Remaja. Jurnal Bimbingan Dan Konseling. Jurnal At-Taujih Bimbingan dan Konseling Islam. Vol 3, No 1: 8698.

Atum Maria, L. H. (2019). Analyzing The Perpetrators Of Klitih Based On The Criminal Profiling In Yogyakarta Regional Police. Doctoral Dissertation, Universitas Ahmad Dahlan.
Fuadi, A., Muti'ah, T., \& Hartosujono. (2019). Faktor-Faktor Determinasi Perilaku Klitih. Jurnal Spirits: Khasanah Psikologi Nusantara, 9(2), 88-98.

Hastasari, Chatia., Suranto, Aw., Hajaroh, Mami. (2018). Family's Communication Pattern In Preventing Student's Violence In Yogyakarta. INFORMASI: Kajian IImu Komunikasi, 48 (2), 155168.

Hawkins, J. D., \& Weis, J. G. (2017). The Social Development Model: An Integrated Approach To Delinquency Prevention. In Developmental And LifeCourse Criminological Theories (Pp. 327). Routledge

Hidayat, M. I. (2018). Efektivitas Pendekatan Restorative Justice Terhadap Kekerasan Klitih Di Yogyakarta Di Tinjau Dari Undang-Undang Nomor 11 Tahun 2012 Tentang Sistem Peradilan Pidana Anak. Doctoral Dissertation, Universitas Bangka Belitung.

Julianto, Alfin. (2019). Kolaborasi Pendidikan Nonformal, Informal, Dan Formal Dalam Pendidikan Pemuda Di Daerah Istimewa Yogyakarta. Jurnal Pendidikan Luar Sekolah, 3 (1), 14-22.

Karlina, L. (2020). Fenomena Terjadinya Kenakalan Remaja. Jurnal Edukasi Nonformal, 1(1), 147-158.

Kumper, Karol L., Turner, Charles W. (1991). The Social Ecology Model Of Adolescent Substance Abuse: Implications For Prevention. The International Journal Of The Addictions, 25 (4A), 435-463.

Leonardus, F.P., \& Nugroho Hastanti Widi., (2017). Nilai-Nilai Moral Keluarga Menurut Etika Jawa Franz Magnis Suseno Sebagai Alternatif Pemecahan Masalah Kasus Klitih. Skripsi. IImu Filsafat, Universitas Gajah Mada.

Maksum, Khanif, And Ahmad Arifin. MODELING: Jurnal Program Studi PGMI 6, No. 2 (September 30, 2019): 259-277.

Maulana, M. A. (2019). Studi Kasus Kenakalan Remaja Tingkat Sekolah Menengah Pertama Di Kota Sukoharjo. Jurnal Pendidikan Dan Pemebelajaran, 4(2), 91-98.

Moranita, M. Erita., Huda, Johan Nasrul. (2019). The Dynamics Of Adolescent Self-Concept In Lembaga Pembinaan Khusus Anak Wonosari Yogyakarta. Jurnal Psikologi Integratif. Vol 7, No 2. Hal 104-121. 


\title{
99 PSIKOPEDAGOGIA
}

\author{
JURNAL BIMBINGAN DAN KONSELING
}

Vol.10, No.2, December 2021

Muawanah, Lis Binti., Suroso., Pratikno, Herlan. (2012). Kematangan Emosi, Konsep Diri Dan Kenakalan Remaja. Jurnal Persona. 1(1), 6-14.

Peiying, Wang. (2011) Analysis Of The Causes Of Juvenile Delinquency Based On The Sociological Angle. IEEE International Conference On Management And Service Science.

Saputra, W. E. S., \& Handaka, I. B. (2017). Konseling Kedamaian: Strategi Konselor Untuk Mereduksi Perilaku Agresi Remaja. Makalah. Prosiding Seminar Nasional Pendidikan Pancasila Dan Kewarganegaraan III 2017.

Saputra, Wahyu N., Supriyanto, Agus., Astuti, Budi., Ayriza, Yulia. (2020). Konseling Kedamaian Berbasis Kearifan Lokal: Strategi Konselor Mereduksi Perilaku Agresi. Yogyakarta: K-Media

Sarwono, R. Budi (2017) Mengendalikan Kegaduhan Sosial "Klithih" Dengan Ketahanan Keluarga. Proceeding Seminar Dan Lokakarya Nasional Revitalisasi Laboratorium Dan Jurnal Ilmiah Dalam Implementasi Kurikulum Bimbingan Dan Konseling Berbasis $\mathrm{KKNI}, 4$ - 6 Agustus 2017, Malang, Jawa Timur, Indonesia.

Sukirno, S. (2018). Pencegahan Klitih Melalui Pendekatan Budaya Baca Pada Siswa Di Daerah Istimewa Yogyakarta. Jurnal IPI (Ikatan Pustakawan Indonesia), 3(1), 28-37.

Surwandono, S., \& Bahari, D. M. K. (2020). The Advocay Of Facebook Public Group "Info Cegatan Jogja" To Prevent Gangsterism Action "Klitih" In Yogyakarta, Indonesia. Society, 8(2), 343-358.

Wiryawan, A.D. \& Yeremias, T.K. (2021). Klitih Di Kota Yogyakartacollaborative Governance Di Dalam Manajemen Risiko Penanganan Kejahatan . Skripsi. UGM. S1 Manajemen dan Kebijakan Publik. 